\title{
Penerapan Model Pembelajaran Inkuiri Terbimbing untuk Meningkatkan KPS dan Hasil Belajar Siswa SMP Kelas VIII
}

\author{
I. Iswatun ${ }^{1}{ }^{*}$, M. Mosik ${ }^{1}$, Bambang Subali ${ }^{1}$ \\ ${ }^{1}$ Pendidikan Fisika, Program Sarjana, Universitas Negeri Semarang. Jalan Sekaran, Gunung Pati, \\ Semarang 50229 Jawa Tengah, Indonesia \\ * Corresponding Author. Email: iswatuniswa0@gmail.com \\ Received: 14 July 2017; Revised: 3 October 2017; Accepted: 25 October 2017
}

\begin{abstract}
Abstrak
Penelitian ini bertujuan untuk meningkatkan keterampilan proses sains (KPS) dan hasil belajar kognitif siswa melalui model pembelajaran inkuiri terbimbing serta untuk mengetahui korelasi KPS terhadap hasil belajar kognitif. Populasi dalam penelitian ini adalah siswa kelas VIII SMP Negeri 1 Bojong Kabupaten Pekalongan tahun ajaran 2016/2017. Penelitian ini merupakan penelitian quasi experiment dengan desain control group pretest posttest. Pengambilan data dilakukan dengan metode tes dan observasi. Pembelajaran inkuiri terbimbing diterapkan pada kelas eksperimen sedangkan Direct Instruction (DI) diterapkan pada kelas kontrol. Hasil penelitian menunjukkan peningkatan KPS kelas eksperimen sebesar 0,52 sedangkan kelas kontrol sebesar 0,33. Pada penelitian ini, aspek keterampilan proses sains yang memperoleh hasil optimal adalah aspek observasi, mengukur, melakukan percobaan, dan komunikasi. Peningkatan hasil belajar kognitif kelas eksperimen sebesar 0,53 sedangkan kelas kontrol sebesar 0,38. Berdasarkan hasil penelitian tersebut menunjukkan bahwa peningkatan kelas eksperimen baik KPS maupun hasil belajar kognitif lebih tinggi dibandingkan kelas kontrol. Hasil uji korelasi pearson menunjukkan bahwa KPS memberikan pengaruh positif terhadap hasil belajar kognitif siswa dengan hasil output korelasi pearsonr(35)=0,554; $p<0,01$. Sehingga dapat disimpulkan bahwa penerapan model pembelajaran inkuiri terbimbing dapat meningkatkan KPS dan hasil belajar kognitif siswa serta memberikan pengaruh positif antara KPS terhadap hasil belajar kognitif siswa.
\end{abstract}

Kata Kunci: inkuiri terbimbing, keterampilan proses sains, hasil belajar kognitif

\section{Application of Guided Inquiry Learning Model to Improve SPS and Student Learning Outcomes for Junior High School Grade VIII}

\begin{abstract}
The aim of this reseach is to improve the Science Prosess Skill (SPS) and to find out the student cognitive learning outcomes by guided inquiry learning models and also to find out the corelation of SPS and student's learning outcomes. The populations of this reseach is 8th grade of SMP Negeri 1 Bojong's students on 2016/2017 school year, in Pekalongan city. The kind of this research is quasy experimental research used control group pretest posttest design. The datas took by test and observation method. Guided inquiry learning was applied in experimental class while direct instruction was applied in control class instead. The results of this research shown 0.52 for experimental class while 0.33 for control class in improvement of SPS. In this research, the aspects of improvement of SPS which got optimal result is observation, measurement, experiment, dan comunications aspect. The improvement of cognitive learning outcomes for experimental class is 0.53 while 0.38 for control class. Based on the results of this research, experimental class got higher point for SPS and cognitive learning outcomes than control class. The result of analisys in pearson corelation shown that SPS gave more positive effect for student cognitive learning outcomes at points $r(35)=0.554 ; p<0.01$ for pearson corelation score. From this research can be conclude that applyng the guided inquiry learning models can improve SPS and student cognitive learning outcomes and also give more positive effect of SPS in student cognitive learning outcomes.
\end{abstract}

Keywords: guided inquiry, science process skills, cognitive learning outcomes

How to Cite: Iswatun, I., Mosik, M., \& Subali, B. (2017). Penerapan model pembelajaran inkuiri terbimbing untuk meningkatkan KPS dan hasil belajar siswa SMP kelas VIII. Jurnal Inovasi Pendidikan IPA, 3(2), 150-160. doi:http://dx.doi.org/10.21831/jipi.v3i2.14871 


\section{Jurnal Inovasi Pendidikan IPA, 3 (2), 2017 - 151}

I. Iswatun, M. Mosik, Bambang Subali

\section{PENDAHULUAN}

Proses pembelajaran Ilmu Pengetahuan Alam (IPA), harus disesuaikan dengan kebijakan yang berlaku sebagai salah satu mata pelajaran di sekolah. Berdasarkan Lampiran Permendiknas nomor 22 tahun 2006. Mata pelajaran IPA berkaitan dengan cara mencari tahu tentang alam secara sistematis, sehingga IPA bukan hanya penguasaan kumpulan pengetahuan yang berupa fakta-fakta, konsep-konsep, atau prinsipprinsip saja tetapi juga merupakan suatu proses penemuan (inquiry).

Proses belajar mengajar IPA lebih ditekankan pada pendekatan keterampilan proses, hingga siswa dapat menemukan fakta-fakta, membangun konsep-konsep, teori-teori dan sikap ilmiah siswa (Trianto, 2010, p. 143).

Melatihkan keterampilan proses dalam pelaksanaannya diawali oleh pemodelan guru, kemudian siswa diminta untuk bekerja dan berlatih sesuai dengan petunjuk dan bimbingan guru (Trianto, 2010, p. 149). Hal ini karena guru mempunyai peran penting untuk mengajarkan keterampilan proses sains di kelas melalui perencanaan dan mengatur kegiatan belajar mengajar untuk mencapai informasi ilmiah.

Keterampilan proses sains berfungsi sebagai tumpuan untuk keterampilan kognitif lainnya seperti berpikir logis, penalaran dan keterampilan pemecahan masalah (Rauf, Rasul, Mansor, Othman, \& Lyndon, 2013). Untuk meningkatkan keterampilan proses sains siswa dapat dilakukan dengan pembelajaran berbasis laboratorium.

Pembelajaran berbasis laboratorium memberikan kesempatan lebih besar bagi siswa untuk mengembangkan keterampilan proses sains Sukarno, Permanasari, \& Hamidah (2013). Pada penelitian ini, pengembangan keterampilan proses sains siswa dalam kegiatan belajar ilmu pengetahuan dan pembelajaran masih relatif rendah. Data menunjukkan bahwa sebanyak $43,48 \%$ kategori rendah, 30,43\% kategori sedang dan $26,09 \%$ dari kategori tinggi.

Rendahnya keterampilan proses sains pada penelitian tersebut dikarenakan kurangnya pemahamanan dan pengetahuan guru dalam menerapkan pembelajaran yang mengarah pada keterampilan proses sains. Serta kurangnya pengembangan bahan ajar yang secara khusus mampu mengarahkan guru dan siswa untuk praktek keterampilan proses sains.

Peningkatan keterampilan proses sains perlu dilakukan untuk mengembangkan kemam- puan siswa dalam belajar IPA melalui pembinaan keterampilan proses yaitu keterampilan sosial, dan fisik diproses untuk memperoleh ilmu pengetahuan yang lebih baik. Peningkatan keterampilan proses sains ini dapat dilakukan dengan penerapan model pembelajaran yang mengajak siswa untuk mencari, menemukan dan memahami konsep-konsep materi. Salah satu model yang bertujuan untuk menemukan dan menguasai konsep materi adalah model pembelajaran inkuiri terbimbing.

Model pembelajaran inkuiri terbimbing adalah satu pendekatan mengajar dimana guru memberi siswa contoh-contoh topik spesifik dan memandu siswa untuk memahami topik tersebut (Eggen \& Kauchak, 2012, p. 177). Pada tahap ini dalam proses pembelajaran siswa mendapatkan bimbingan dari guru untuk mendapatkan jawaban suatu permasalahan.

Keunggulan model pembelajaran inkuiri terbimbing adalah efektif untuk meningkatkan motivasi siswa. Hal ini karena siswa mempunyai tingkat keterlibatan yang tinggi dalam proses pembelajaran, proses ini melibatkan siswa untuk berusaha menemukan konsep atau pemahaman pada topik yang diberikan guru. Selain itu, rasa ingin tahu siswa yang tinggi dari proses pembelajaran tersebut (Eggen \& Kauchak, 2012, p. 201).

Selain memiliki keunggulan, model pembelajaran inkuiri dapat mengakomodasi siswa dalam melatihkan keterampilan proses sains melalui tahap pembelajaran yang dimiliki. Tahap pembelajaran model inkuiri terdiri dari observasi, mengajukan pertanyaan (merumuskan permasalahan), merumuskan hipotesis, merancang percobaan, melaksanakan percobaan, mengumpulkan data, analisis data, argumentasi. (Scott, Tomasek, \& Matthews, 2010).

Berdasarkan lampiran permendiknas no 20 tahun 2006. Model pembelajaran inkuiri terbimbing disarankan untuk diterapkan dalam pembelajaran IPA.Hal ini untuk menumbuhkan kemampuan berpikir, bekerja, dan bersikap ilmiah serta mengkomunikasikannya sebagai aspek penting kecakapan hidup.

Inkuiri terbimbing berbasis laboratorium mempunyai pengaruh positif yang signifikan terhadap hasil belajar dan sikap ilmiah siswa (Maretasari, Subali, \& Hartono, 2012). Hasil penelitian ini diperoleh peningkatan gain hasil belajar sebesar 0,53 dan peningkatan gain sikap ilmiah sebesar 0,31 .

Penggunaan metode inkuiri terbimbing direkomendasikan untuk diterapkan dalam mata 
pelajaran IPA untuk meningkatkan keterampilan proses sains siswa. Penelitian yang dilakukan oleh Akinbobola \& Afolabi (2010) menunjukkan bahwa jumlah keterampilan proses dasar secara signifikan lebih tinggi daripada keterampilan poses terintegrasi. Hal ini dikarenakan seringnya penggunaan model pembelajaran yang berpusat pada guru. Namun analisis lima tahun terakhir menunjukkan hasil yang stabil pada keterampilan berkomunikasi. Hal ini disebabkan karena pembelajaran yang berpusat pada guru telah begeser pada pembelajaran yang berpusat pada anak seperti pemecahan masalah, penemuan dan metode penyelidikan.

Bilgin (2009) menggambarkan guided inquiry sebagai pendekatan yang berpusat pada siswa. Pendekatan ini memiliki pengaruh positif terhadap keberhasilan akademik siswa dan sikap ilmiah. Hasil penelitian yang dilakukan oleh Bilgin (2009) menunjukkan hasil yang signifikan setelah menggunakan model guided inquiry.

Guided Inquiry adalah satu pendekatan mengajar dimana guru memberi siswa contohcontoh topik spesifik dan memandu siswa untuk memahami topik tersebut (Eggen \& Kauchak, 2012). Selain itu, pembelajaran guided inquiry menciptakan efektivitas dan efisiensi waktu yang tinggi dalam mengajar karena pembelajaran berpusat pada siswa dan peran guru hanya sebatas fasilitator dan pengarah atau pembimbing siswa (Yuniastuti, 2013).

Berdasarkan hasil observasi yang dilakukan di SMP Negeri 1 Bojong, Kabupaten Pekalongan menunjukkan bahwa siswa masih cenderung pasif dalam proses pembelajaran. Hal ini terjadi disebabkan guru lebih sering menggunakan metode ceramah dibanding metode yang lainnya.

Pada keadaan sebenarnya kegiatan belajar mengajar di sekolah sudah tersedia kit percobaan yang lengkap tetapi kurang perawatan. Selain itu, pada semester ini guru tidak pernah melakukan kegiatan keterampilan proses dalam pembelajaran seperti kegiatan laboratorium. Sehingga pelajaran fisika menjadi monoton dan membosankan karena pembelajaran hanya berpusat pada guru teacher centered. Siswa menjadi tidak termotivasi untuk belajar fisika yang mengakibatkan keterampilan proses sains tidak berkembang.

Berdasarkan hasil observasi dan hasil penelitian sebelumnya maka diperlukan upaya tindak lanjut agar tujuan pembelajaran dapat tercapai secara optimal. Salah satu upaya tersebut adalah penggunaan suatu strategi pembel- ajaran yang sesuai. Strategi pembelajaran yang dapat meningkatkan keterampilan proses sains dan hasil belajar adalah strategi pembelajaran inkuiri terbimbing yang dipadukan dengan metode eksperimen. Aspek keterampilan proses sains yang akan dikembangkan dalam penelitian meliputi aspek mengamati, mengukur, menyusun hipotesis, merencanakan eksperimen, melakukan eksperimen, mengolah data, inferensi, dan komunikasi,

\section{METODE}

Penelitian ini dilaksanakan di SMP Negeri 1 Bojong Kabupaten Pekalongan. Populasi dalam penelitian ini adalah siswa kelas VIII SMP Negeri 1 Bojong Tahun Ajaran 2016/2017. Pengambilan sampel pada penelitian ini menggunakan teknik purposive sampling sehingga diperoleh kelas VIII C sebagai kelas eksperimen dan kelas VIII D sebagai kelas kontrol. Penelitian ini menggunakan metode penelitian quasi experiment dengan desain control group pretest posttest.

Setelah diberikan pretest, kelas eksperimen dan kelas kontrol pada pertemuan pertama mendapatkan perlakuan sama yaitu menggunakan model pembelajaran Direct Instructure (DI). Pada pertemuan kedua, kelas eksperimen dan kelas kontrol mendapatkan perlakuan yang berbeda.Pembelajaran di kelas eksperimen menggunakan model pembelajaran inkuiri terbimbing sedangkan pembelajaran di kelas kontrol menggunaka model pembelajaran Direct Instructure.

Metode pengumpulan data yang digunakan adalah metode dokumentasi, metode tes dan metode observasi. Metode dokumentasi dilakukan untuk mendapatkan data awal siswa yang menjadi sampel berupa daftar nama siswa dan nilai ujian akhir sekolah semester gasal. Tes uraian digunakan untuk menentukan peningkatan hasil belajar kognitif siswa pada materi pemantulan cahaya. Lembar observasi digunakan untuk menentukan peningkatan keterampilan proses sains siswa yang berisi sebuah daftar jenis kegiatan yang diamati dan kolom skor. Lembar observasi digunakan pada setiap proses pembelajaran khususnya saat melakukan eksperimen sebanyak dua kali pertemuan.

Analisis data yang dilakukan meliputi analisis uji coba soal tes uraian berupa uji validitas, reliabilitias, daya pembeda dan taraf kesukaran, analisis data tahap awal berupa uji homogenitas, dan uji normalitas serta analisis data tahap akhir berupa uji normalitas, uji 
homogenitas, uji t atau independent samples $t$ test, uji $\mathrm{N}$-Gain, uji korelasi pearson, dan koefisien determinasi. Uji normalitas digunakan untuk mengetahui apakah data yang akan dianalisis terdistribusi secara normal atau tidak. Uji homogenitas digunakan untuk mengetahui apakah memiliki varian yang sama (homogen) atau tidak. Uji $\mathrm{t}$ atau independent samples $t$ testdigunakan untuk mengetahui apakah ada perbedaan nilai rata-rataposttest hasil belajar kognitif dan keterampilan proses sains siswa antara kelas kontrol dan kelas eksperimen. Uji $\mathrm{N}$-Gain digunakan untuk mengetahui peningkatan data hasil tes uraian dan hasil observasi kelas kontrol dan kelas eksperimen, uji korelasi pearson digunakan untuk mengetahui hubungan keterampilan proses sains terhadap hasil belajar kognitif dan koefisien determinasi.

\section{HASIL DAN PEMBAHASAN}

\section{Peningkatan Keterampilan Proses Sains}

Nilai Keterampilan Proses Sains (KPS) siswa diperoleh melalui observasi selama proses pembelajaran berlangsung. Hasil observasi KPS yang diamati merupakan hasil belajar psikomotorik. Penilaian KPS siswa meliputi aspek: observasi, mengukur, menyusun hipotesis, merencanakan percobaan, melakukan percobaan, mengolah data, menginterfernsi, dan komunikasi.

Penelitian dilakukan pada saat pembelajaran berlangsung menggunakan lembar observasi. Pada pertemuan pertama kelas kontrol dan kelas eksperimen menggunakan model pembelajaran direct instruction (DI) untuk mendapatkan data pretest keterampilan proses sains. Pada pertemuan kedua kelas kontrol menggunakan model pembelajaran DI, sedangkan kelas eksperimen mendapatkan perlakuan menggunakan model pembelajaran inkuiri terbimbing untuk mendapatkan data posttest KPS.
Hasil perhitungan uji $\mathrm{N}$-Gain nilai keterampilan proses sains kelas kontrol diperoleh sebesar 0,33 termasuk kategori sedang sementara kelas eksperimen sebesar 0,52 termasuk kategori sedang. Hasil analisis tersebut menunjukkan bahwa peningkatan KPS siswa eksperimen lebih besar dibanding kelas kontrol.Nilai KPS dan uji $\mathrm{N}$-Gain kelas kontrol dan kelas eksperimen disajikan pada Tabel 1.

Berdasarkan hasil analisis diperoleh bahwa pada setiap eksperimen yang dilakukan nampak KPS siswa mengalami peningkatan. Baik ditinjau dari skor total maupun skor dari setiap aspek KPS yang diamati. Rata-rata nilai KPS eksperimen I pada kelas kontrol sebesar 48,57 sementara pada kelas eksperimen sebesar 50,89. Hasil penilaian KPS eksperimen I menunjukan bahwa hampir sebagian besar siswa belum baik dalam KPS. Hal ini dikarenakan siswa belum terbiasa dengan kegiatan percobaan dan eksperimen I merupakan percobaan kali pertama pada kelas VIII baik semester ganjil maupun semester genap. Kemudian saat melakukan penilaian KPS eksperimen II diperoleh rata-rata nilai pada kelas kontrol sebesar 65,36 dan pada kelas eksperimen sebesar 76,34

Analisis uji perbedaan nilai rata-rata posttest KPS antara kelas kontrol dan kelas eksperimen menunjukkan bahwa terdapat perbedaan yang signifikan nilai rata-rata posttest KPS antara kelas kontrol dan kelas eksperimen. Selain itu, nilai rata-rata posttest kelas eksperimen lebih tinggi dari kelas kontrol.

Tabel 1 menunjukkan bahwa pembelajaran inkuiri terbimbing dapat meningkatkan KPS siswa pada materi pemantulan cahaya dibanding model pembelajaran DI. Hasil peningkatan tiap aspek KPS berdasarkan nilai ekperimen I dan eksperimen II pada kelas kontrol disajikan pada Gambar 1.

Tabel 1 Nilai rata-rata KPS kelas kontrol dan kelas eksperimen

\begin{tabular}{ccccc}
\hline \multirow{2}{*}{ Kategori } & \multicolumn{2}{c}{ Kelas Kontrol } & \multicolumn{2}{c}{ Kelas Eksperimen } \\
\cline { 2 - 6 } & Eksperimen I & Eksperimen II & Eksperimen I & Eksperimen II \\
\hline Nilai Terendah & 34,38 & 50,00 & 34,38 & 53,13 \\
Nilai Teringgi & 62,50 & 75,00 & 68,75 & 90,63 \\
Rata-rata & 48,57 & 65,36 & 50,89 & 76,34 \\
N-Gain & \multicolumn{2}{c}{0,33} & \multicolumn{3}{c}{0,52} \\
Kriteria & \multicolumn{2}{c}{ Sedang } & \multicolumn{3}{c}{} \\
\hline
\end{tabular}




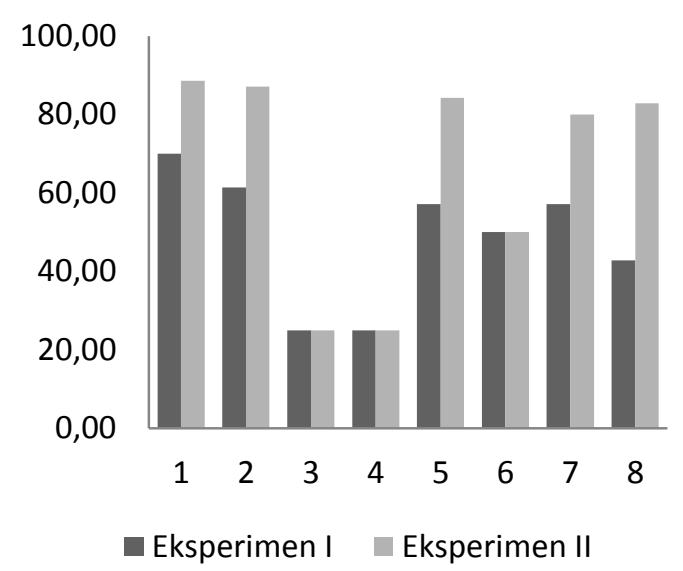

Gambar 1. Grafik Peningkatan Aspek KPS Kelas Kontrol

Peningkatan tiap aspek keterampilan proses sains berdasarkan nilai ekperimen I dan eksperimen II pada kelas eksperimen disajikan pada Gambar 2.

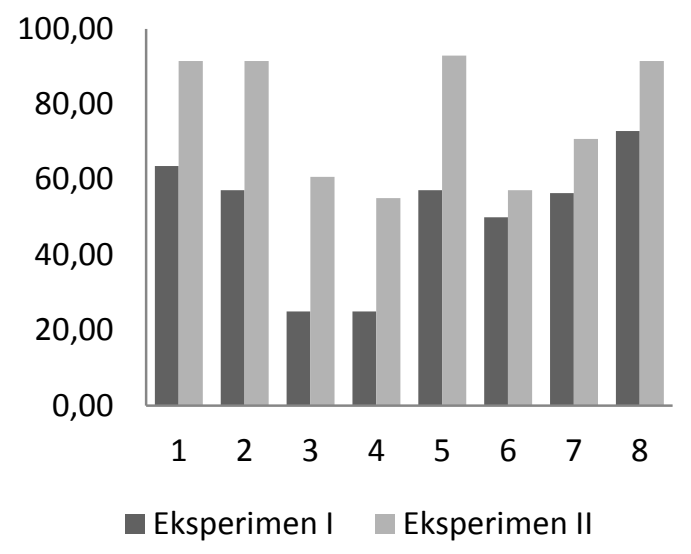

Gambar 2 Grafik Peningkatan Aspek KPS Kelas Eksperimen

Peningkatan keterampilan proses sains berdasarkan rata-rata niai eksperimen I dan eksperimen II antara kelas kontrol dan kelas eksperimen disajikan pada Gambar 3.

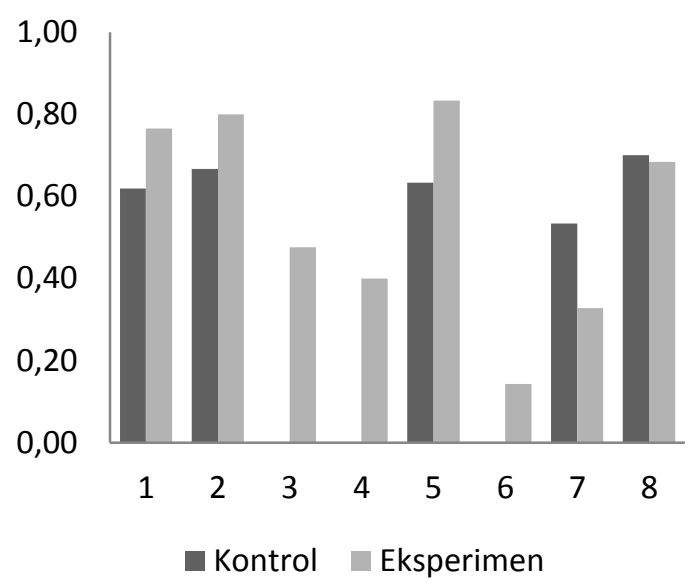

Gambar 3. Grafik Peningkatan Setiap Aspek KPS pada Kelas Kontrol dan Kelas Eksperimen

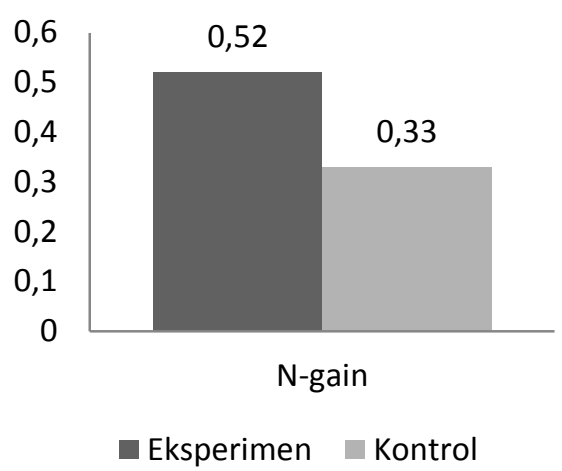

Gambar 4. Grafik N-Gain Seluruh Aspek KPS Kelas Kontrol dan Kelas Eksperimen

Model pembelajaran guided inquiry dalam penelitian ini menggunakan metode eksperimen. Kegiatan eksperimen dapat meningkatkan kepercayaan diri dalam mendapatkan informasi. Sehingga kegiatan laboratorium berbasis guided inquiry ini diperlukan untuk dapat meningkatkan hasil pembelajaran (Ural, 2016) dan keterampilan proses sains siswa (Ratunguri, 2016).

Penerapan model pembelajaran guided inquiry bertujuan untuk meningkatkan keterampilan proses sains siswa meliputi keterampilan observasi, mengukur, menyusun hipotesis, merencanakan percobaan, melakukan percobaan, mengolah data, interferensi dan komunikasi.

Model pembelajaran guided inquiry yang melibatkan proses secara ilmiah melalui eksperimen mampu meningkatkan keterampilan proses sains dasar (Ambarsari, Santosa, \& Maridi, 2013). Selain itu, menurut Abungu, Okere, \& Wachanga (2014) menyatakan bahwa ketika siswa melakukan eksperimen maka siswa akan melatih keterampilan dan kemampuan proses mereka. Sehingga keterampilan ilmiah memberikan dampak prestasi secara keseluruhan. Hal ini sesuai dengan hasil penelitian bahwa kelas eksperimen mengalami peningkatan keterampilan proses sains lebih baik dari kelas kontrol.

Berdasarkan hasil penelitian semua aspek pada penelitian ini mengalami peningkatan $\mathrm{N}$ Gain, namun aspek inferensi dan komunikasi pada kelas eksperimen mengalami peningkatan $N$-Gain yang lebih kecil dari kelas kontrol.

Peningkatan keterampilan observasi lebih tinggi di kelas eksperimen daripada kelas kontrol. Hal ini dikarenakan keterampilan observasi adalah keterampilan utama yang harus dimiliki siswa untuk memulai penyelidikan dalam pene- 


\section{Jurnal Inovasi Pendidikan IPA, 3 (2), 2017 - 155}

I. Iswatun, M. Mosik, Bambang Subali

muan suatu masalah. Selain itu, keterampilan observasi mempunyai peran penting dalam penyelidikan sains dan pembentukan pengetahuan ilmiah. Siswa dapat melakukan keterampilan sederhana ketika sekedar melihat benda untuk menyatakan sesuatu secara konkret. Observasi dapat dikatakan sebagai ketarampilan yang kompleks ketika diterapkan untuk memberikan penjelasan lebih jauh dan menghasilkan teori terkait fenomena yang diobservasi (Ahtee, Suomela, Juuti, Lampiselkä, \& Lavonen, 2012). Berbeda dengan model pembelajaran DI dimana siswa hanya mengamati apa yang diperintahkan.

Berdasarkan nilai faktor $\mathrm{N}$-Gain dan nilai rata-rata eksperimen terakhir dapat disimpulkan bahwa model pembelajaran guided inquiry dapat meningkatkan keterampilan observasi. Hal ini sesuai dengan hasil penelitian Ambarsari, Santosa, \& Maridi (2013) yang menyatakan bahwa model pembelajaran guided inquiry dapat meningkatkan keterampilan proses sains dimana salah satu aspeknya yaitu observasi.

Peningkatan keterampilan mengukur di kelas eksperimen lebih tinggi daripada kelas kontrol. Hal ini dikarenakan kelas eksperimen sudah menyiapkan percobaan dengan mencari rencana percobaan sebelum melakukannya sebagai langkah dari pembelajaran guided inquiry.

Peningkatan keterampilan menyusun hipotesis pada kelas eksperimen termasuk kategori sedang. Sedangkan pada kelas kontrol aspek keterampilan menyusun hipotesis tidak mengalami peningkatan disebabkan karena perlakukan yang diberikan di kelas kontrol berupa pembelajaran DI, sehingga siswa tidak dituntut untuk berhipotesis. Pembelajaran guided inquiry melatih siswa untuk menyusun hipotesis terhadap rumusan masalah yang disajikan, berbeda dengan pembelajaran DI yang tidak menyajikan masalah sehingga hipotesis tidak dapat dirumuskan. Jadi keterampilan hipotesis merupakan salah satu bagian dari proses pembelajaran guided inquiry yang belum tentu diperoleh dalam model pembelajaran lainnya.

Peningkatan keterampilan merencanakan percobaan pada kelas eksperimen termasuk kategori sedang, sedangkan kelas kontrol tidak memiliki keterampilan merencanakan percobaan karena menggunakan model pembelajaran DI, sehingga siswa tidak dituntut untuk merencanakan percobaan. Pada model guided inquiry, aspek keterampilan merencanakan percobaan merupakan salah satu langkah yang dibutuhkan untuk melakukan kegiatan penemuan. Selain itu, merencanakan percobaan merupakan salah satu tahap pembelajaran pembelajaran inkuiri (Scott et al., 2010). Pada kelas eks-perimen siswa diberi tugas untuk mencari dan mempelajari langkah-langkah percobaan sebelum melakukan percobaan.

Peningkatan keterampilan melakukan percobaan pada kelas eksperimen lebih tinggi daripada kelas kontrol. Hal ini menunjukkan bahwa model pembelajaran guided inquiry dapat meningkatkan keterampilan melakukan percobaan dibanding dengan model pembelajaran DI. Hal ini sejalan dengan hasil penelitian Rahmasiwi, Santosari, \& Sari (2015) teradapat peningkatan melakukan percobaan dengan menggunakan model pembelajaran inkuiri. Serta hasil penelitian Subagyo, Wiyanto, \& Marwoto (2012) yang menggunakan LKS berbasis inkuiri.

Keterampilan mengolah data di kelas eksperimen meningkat lebih baik daripada di kelas kontrol, sedangkan kelas kontrol tidak memiliki keterampilan mengolah data karena LKS yang digunakan tidak berbasis inkuiri. Kelas eksperimen menganalisis data mengacu pada rumusan masalah yang diberikan dan disediakan pada LKS yang berbasis inkuiri.

Pada keterampilan mengolah data, siswa belum terbiasa mengubah data tabel menjadi grafik sehingga siswa mengalami kesulitan dalam membuat grafik dan menentukan variabel bebas untuk dijadikan sumbu $\mathrm{x}$ dan variabel terikat sebagai sumbu y. Namun dengan adanya bimbingan dari guru, siswa belajar mengolah data dengan mengubah data dalam tabel menjadi grafik. Sehingga siswa memiliki bekal pengetahuan dasar yang baik dalam keterampilan mengolah data.

Pada aspek inferensi menunjukkan bahwa kelas kontrol lebih baik daripada kelas eksperimen.Hal ini disebabkan karena siswa pada kelas eksperimen belum terbiasa dengan perlakuan menggunakan model pembelajaran guided inquiry.Tidak adanya pembagian tugas mengakibatkan kekurangan waktu dalam menyelesaikan percobaan. Salah satu hambatan dalam menerapkan model pembelajarn guided inquiry adalah kekurangan waktu (Cheung, 2007).

Percobaan berbasis inkuiri membutuhkan waktu lebih lama untuk menyelesaikannya karena siswa membutuhkan waktu tambahan untuk merencanakan percobaan, dan mengolah data. Maka solusinya perlu ditingkatkan jam kegiatan laboratorium (Ural, 2016).

Pada aspek komunikasi menunjukkan bahwa kelas kontrol lebih baik daripada kelas 
eksperimen. Hal ini disebabkan karena keterampilan awal komunikasi pada kelas eksperimen sudah baik sehingga hasil peningkatannya sedikit atau rendah. Berbeda dengan kelas kontrol yang mempunyai kemampuan awal komunikasinya rendah sehingga hasil peningkatannya sedang. Tetapi hasil menunjukkan tetap adanya peningkatan keterampilan komunikasi di kelas eksperimen. Hasil ini sesuai dengan hasil penelitian Likayati dan Ismono (2016) menunjukkan bahwa dengan model pembelajaran guided inquiry dapat meningkatkan keterampilan proses sains yang salah satu aspeknya yaitu keterampilan komunikasi.

Pada penelitian ini, aspek keterampilan proses sains yang memperoleh hasil optimal adalah aspek observasi, mengukur, melakukan percobaan, dan komunikasi. Penelitian yang dilakukan oleh Rahmasiwi, Santosari, \& Sari (2015) menyatakan bahwa aspek komunikasi belum optimal karena belum mencapai target minimalnya. Sedangkan hasil penelitian Amalia (2015) menyatakan bahwa peningkatan aspek mengukur pada kelas eksperimen lebih rendah dari kelas kontrol. Dari hasil kedua penelitian tersebut, maka dapat dikatakan bahwa pada penelitian ini penerapan model pembelajarn guided inquiry mampu meningkatkan keterampilan proses sains siswa.

Secara keseluruhan semua aspek keterampilan proses sains pada kelas eksperimen mempunyai nilai peningkatan yang lebih tinggi dibanding dengan nilai peningkatan kelas kontrol.

Berdasarkan hasil penelitian yang saya lakukan didapatkan nilai faktor $\mathrm{N}$-Gain kelas kelas eksperimen 0,54 lebih besar dari kelas kontrol 0,33 . Sedangkan pada penelitian sebelumnya oleh Subagyo, Wiyanto, \& Marwoto (2012) yang memiliki kesamaan dalam penelitian ini didapatkan hasil nilai peningkatan N-Gain keterampilan proses sains sebesar 0,478. Sedangkan hasil penelitian Saputra, Widoretno, \& Santosa (2012) menghasilkan nilai rata-rata KPS sebesar 68,48.Selain itu, hasil penelitian Rahmazani (2017) menghasilkan nilai peningkatan N-Gain keterampilan proses sains sebesar 0,49. Hal ini menunjukkan bahwa penelitian yang saya lakukan mendapatkan hasil yang lebih baik dari penelitian yang sebelummya.

Maka dapat disimpulkan bahwa model pembelajaran guided inquiry dapat meningkatkan keterampilain proses sains siswa. Sejalan dengan hasil penelitian Ongowo \& Indoshi
(2013) menegaskan bahwa keterampilan proses sains dapat dikembangkan melalui implementasi pembelajaran yang didasarkan pada penemuan melalui penyelidikan yaitu model pembelajran inkuiri.

\section{Peningkatan Hasil Belajar Kognitif}

Hasil belajar kognitif siswa diukur dari nilai rata-rata pretest dan posttest. Hasil analisis rata-rata pretest, posttest dan peningkatan hasil belajar kognitif siswa disajikan dalam Tabel 2

Tabel 2 Nilai rata-rata hasil belajar kognitif kelas kontrol dan kelas eksperimen

\begin{tabular}{ccccc}
\hline \multirow{2}{*}{ Kategori } & \multicolumn{2}{c}{ Kelas Kontrol } & \multicolumn{2}{c}{$\begin{array}{c}\text { Kelas } \\
\text { Eksperimen }\end{array}$} \\
\cline { 2 - 5 } & Pretest & Posttest & Pretest & Posttest \\
\hline Nilai & 14,00 & 34,88 & 20,13 & 65,63 \\
Terendah & & & & \\
Nilai & 38,88 & 66,60 & 35,00 & 31,25 \\
Teringgi & 26,07 & 54,20 & 25,52 & 64,67 \\
Rata-rata & 0,38 & \multicolumn{2}{c}{0,53} \\
$N$-Gain & \multicolumn{2}{c}{ Sedang } & \multicolumn{2}{c}{ Sedang } \\
Kriteria & \multicolumn{2}{c}{ Sedang }
\end{tabular}

Tabel 2 menunjukkan bahwa hasil belajar kognitif siswa kelas eksperimen dan kelas kontrol mengalami peningkatan. Meningkatnya hasil belajar kognitif siswa pada kelas eksperimen dan kelas kontrol disebabkan oleh keterlibatan siswa selama proses pembelajaran berlangsung. Model pembelajaran guided inquiry memusatkan pembelajaran pada siswa. Siswa menjadi lebih aktif dalam proses pembelajaran memperoleh pengetahuan melalui pengalaman langsung, bukan hanya sekedar mendengar dan menerima pengetahuan atau informasi dari apa yang dikatakan oleh guru saja (Wijayanti, Mosik, \& Hindarto, 2016).

Berdasarkan hasil analisis data uji-t perbedaan rata-rata nilai posttest hasil belajar kongitif antara kelas eksperimen dan kelas kontrol menunjukkan uji hipotesis menggunakan independent samples $t$ test diperoleh Sig. (2tailed $)<0,05$ menunjukkan bahwa terdapat perbedaan yang signifikan antara rata-rata nilai posttest kelas eksperimen dengan kelas kontrol.

Pembelajaran guided inquiry lebih efektif meningkatkan hasil belajar kognitif siswa pada materi pokok pemantulan cahaya dibanding dengan model pembelajaran DI dengan nifai nilai faktor $N$-Gain kelas eksperimen mencapai 0,53 lebih besar dari nilai faktor $N$-Gain kelas kontrol mencapai 0,38. Sedangkan pada penelitian sebelumnya oleh Subagyo, Wiyanto, \& Marwoto (2012) dan Rahmazani (2017) yang 
memiliki kesamaan dalam penelitian ini didapatkan hasil penelitian peningkatan hasil belajar sebesar 0,219 dan 0,50. Hal ini menunjukkan bahwa penelitian yang saya lakukan mendapatkan hasil yang lebih baik dari penelitian yang sebelummya.

Jadi dapat disimpulkan bahwa model pembelajaran guided inquiry lebih efektif meningkatkan hasil belajar kognitif siswa.Hal ini dikarenakan, model pembelajaran guided inquiry memusatkan pembelajaran pada siswa. Siswa menjadi lebih aktif dalam proses pembelajaran Sejalan dengan hasil penelitian Alanindra dkk (2012)\& Yuniastuti (2013) bahwa model pembelajaran inkuiri dapat meningkatkan hasil belajar kognitif siswa.

Berdasarkan hasil penelitian Murningsih, Masykuri, \& Mulyani (2016) bahwa penerapan model pembelajaran guided inquiry dapat meningkatan hasil belajar aspek kognitif. Hal ini dikarenakan model pembelajaran guided inquiry siswa dibimbing untuk menemukan konsep dari pengamatan sehingga siswa lebih mudah mengabstraksikan ke dalam pikiran.

Walaupun hasil penelitian belum semuanya tercapai dengan hasil yang sangat baik, hal ini dikarenakan siswa belum terbiasa dengan model pembelajaran guided inquiry (Damawiyah \& Sani, 2015). Sehingga dibutuhkan waktu penyesuaian dengan siswa saat proses pembel-ajaran berlangsung. Oleh sebab itu hendaknya dalam proses pembelajaran sebaiknya siswa diajarkan dengan menggunakan model pembel-ajaran yang lebih variatif supaya siswa mampu memahami materi pelajaran secara efektif dan efisien.

\section{Korelasi Keterampilan Proses Sains terhadap Hasil Belajar Siswa}

Untuk mengetahui korelasi keterampilan proses sains terhadap hasil belajar siswa digunakan uji korelasi pearson, dimana variabel bebasnya adalah nilai posttest keterampilan proses sains sedangkan variabel terikatnya adalah nilai posttest hasil belajar kognitif siswa. Kedua variabel telah diuji normalitasnya dan termasuk terdistribusi normal. Hasil output uji korelasi pearson disajikan pada Tabel 3.

Berdasarkan hasil analisis, diperoleh nilai $r(35)=0,554$; hal ini menunjukkan bahwa hubungan antara kedua variabel merupakan positif, termasuk kategori sedang, selain itu $p<0,01$ menunjukkan bahwa hubungan kedua variabel sangat signifikan.

Hal ini sejalan dengan hasil penelitian Yuniastuti (2013) yang menyatakan bahwa penerapan model pembelajaran guided inquiry di dalam kelas memicu terjadinya kenaikan keterampilan proses sains siswa dalam melakukan percobaan sehingga berdampak pada kenaikan motivasi belajar. Sedangkan hasil belajar mengalami peningkatan sebagai dampak dari kenaikan keterampilan proses sains dan motivasi belajar.

Sehingga dapat disimpulkan bahwa semakin besar nilai keterampilan proses sains siswa maka semakin besar pula hasil belajar kognitif siswa. Sebaliknya, semakin kecil nilai keterampilan proses sains siswa maka semakin kecil pula hasil belajar kognitif siswa.

\section{Besarnya Pengaruh Penerapan Model Pembelajaran Guided inquiry terhadap Peningkatan KPS dan Hasil Belajar Siswa}

Untuk mengetahui besarnya pengaruh penerapan model pembelajaran guided inquiry terhadap keterampilan proses sains dan hasil belajar siswa diperoeh dari hasil koefisien determinasi. Berdasarkan hasil analisis koefisien determinasi menunjukkan bahwa besarnya pengaruh model pembelajaran guided inquiry terhadap peningkatan keterampilan proses sains dan hasil belajar kognitif siswa mencapai $30,69 \%$.

Peningkatan keterampilan proses sains mengakibatkan terjadinya peningkatan pada prestasi hasil belajar. Siswa dengan keterampilan proses sains tinggi mampu melakukan percobaan dengan baik, sehingga siswa lebih mudah dalam memahami materi yang diajarkan melalui pelaksanaan percobaan. Hal ini berdampak pada hasil belajar siswa yakni siswa dengan keterampilan proses sains tinggi akan memiliki prestasi kognitif yang lebih baik daripada siswa dengan keterampilan proses sains rendah. Keterampilan proses sains pada siswa dapat terbentuk dan dikembangkan dengan kebiasaan yang dilakukan dan dilatih terus menerus pada proses pembelajaran (Ariani, Hamid, \& Leny, 2017). 
Jurnal Inovasi Pendidikan IPA, 3 (2), 2017 - 158

I. Iswatun, M. Mosik, Bambang Subali

Tabel 3 Hasil Uji Korelasi (Korelasi Pearson) antar Dua Variabel

\begin{tabular}{rlrr}
\hline & & Keterampilan proses Sains & Hasil Belajar Kognitif \\
\hline Keterampilan proses Sains & Pearson Correlation & 1 &, $554^{* *}$ \\
& Sig. (2-tailed) & &, 001 \\
& $\mathrm{~N}$ & 35 & 35 \\
Hasil Belajar Kognitif & Pearson Correlation &, $554^{* *}$ & 1 \\
& Sig. (2-tailed) &, 001 & 35 \\
& $\mathrm{~N}$ & 35 & \\
\hline
\end{tabular}

**. Correlation is significant at the 0.01 level (2-tailed).

Berdasarkan hasil penelitian Kang \& Keinonen (2017) bahwa model pembelajaran guided inquiry memberikan pengaruh positif yang kuat terhadap prestasi siswa dan minat siswa. Hal ini model pembelajaran guided inquiry berorientasi tidak hanya pada hasil belajar tetapi juga berorientasi pada proses pembelajaran. Selain itu, hasil penelitian ini juga sejalan dengan hasil penelitian yang dilakukan oleh Subagyo, Wiyanto, \& Marwoto (2012) bahwa hasil belajar siswa dapat ditingkatkan dengan pendekatan keterampilan proses pada pokok bahasan suhu dan pemuaian.

Berdasarkan hasil penelitian menunjukkan bahwa hasil yang didapatkan sudah sesuai dengan yang diharapkan yakni model pembelajaran guided inquiry dapat memberikan pengaruh positif terhadap keterampilan proses sains dan hasil belajar kognitif siswa. Sesuai dengan hasil penelitian Udiani, Marhaeni, \& Arnyana (2017) bahwa keterampilan proses sains mempunyai pengaruh positif terhadap hasil belajar IPA siswa ketika menggunakan pembelajaran model guided inquiry. Siswa yang diajar dengan model pembelajaran guided inquiry mempunyai keterampilan proses sains yang tinggi dan hasil belajar kognitif lebih tinggi.

Sejalan dengan hasil penelitian Subekti \& Ariswan (2016) bahwa model pembelajaran guided inquiry melalui metode eksperimen memberikan pegnaruh positif yang signifikan terhadap peningkatan keterampilan proses sains dan hasil belajar fisika aspek kognitif

\section{SIMPULAN}

Berdasarkan hasil penelitian yang telah dilakukan, dapat disimpulkan bahwa Model pembelajaran guided inquiry dapat meningkatkan keterampilan proses sains siswa dengan peningkatan 0,52 termasuk kategori sedang serta hasil belajar kognitif siswa dengan peningkatan 0,53 termasuk kategori sedang. Model pembelajaran guided inquiry berpengaruh positif terhadap keterampilan proses sains dan hasil belajar kognitif siswa $r(35)=0,554$. Besarnya pengaruh pembelajaran guided inquiry terhadap keterampilan proses sains dan hasil belajar kognitif siswa sebesar 30,69\%

Berdasarkan simpulan di atas, saran yang dapat direkomendasikan yaitu agar pelaksanaan model pembelajaran guided inquiry dapat dilaksanakan dengan maksimal, diperlukan pengondisian kesiapan siswa dengan menerapkan model pembelajaran guided inquiry secara berkala. Selain itu, perlu dilakukan penelitian lebih lanjut menggunakan model pembelajaran guided inquiry sebagai alternatif untuk meningkatkan keterampilan proses sains siswa dan mengukur aspek lainnya seperti karakteristik siswa.

\section{DAFTAR PUSTAKA}

Abungu, H. E., Okere, M. I. O., \& Wachanga, S. W. (2014). The effect of science process skills teaching approach on secondary school students' achievement in chemistry in Nyando District, Kenya. Journal of Educational and Social Research (Vol. 4). Retrieved from http://www.mcser.org/journal/index.php/j esr/article/view/4101

Ahtee, M., Suomela, L., Juuti, K., Lampiselkä, J., \& Lavonen, J. (2012). Primary school student teachers' views about making observations. Nordic Studies in Science Education, $\quad 5(2), \quad 128$. https://doi.org/10.5617/nordina.346

Akinbobola, A. O., \& Afolabi, F. (2010). Analysis of science process skills in West African senior secondary school certificate physics practical examinations in Nigeria. Bulgarian Journal of Science and Education Policy (BJSEP), 4(1), 3247. Retrieved from http://bjsep.org/getfile.php?id=64

Ambarsari, W., Santosa, S., \& Maridi, M. (2013). Penerapan pembelajaran inkuiri terbimbing terhadap keterampilan proses sains dasar pada pelajaran biologi siswa kelas VIII SMP Negeri 7 Surakarta. 
Pendidikan Biologi, 5(1). Retrieved from http://jurnal.fkip.uns.ac.id/index.php/bio/a rticle/view/1441

Ariani, M., Hamid, A., \& Leny, L. (2017). Meningkatkan keterampilan proses sains dan hasil belajar siswa pada materi koloid dengan model inkuiri terbimbing (guided inquiry) pada siswa kelas XI IPA 1 SMA Negeri 11 Banjarmasin. Quantum (Jurnal Inovasi Pendidikan Sains), 6(1). Retrieved from http://ppjp.unlam.ac.id/journal/index.php/ quantum/article/view/3242

Bilgin, I. (2009). The effects of guided inquiry instruction incorporating a cooperative learning approach on university students' achievement of acid and bases concepts and attitude toward guided inquiry instruction. Scientific Research and Essay, 4(10), 1038-1046. Retrieved from http://www.academicjournals.org/sre

Cheung, D. (2007). Facilitating chemistry teachers to implement inquiry-based laboratory work. International Journal of Science and Mathematics Education, 6(1), 107-130. https://doi.org/10.1007/s10763007-9102-y

Damawiyah, S., \& Sani, R. A. (2015). Pengaruh model pembelajaran inkuiri terbimbing terhadap hasil belajar siswa pada materi pokok usaha dan energy di kelas VIII semester II SMP Negeri 1 Pagajahan. INPAFI (Inovasi Pembelajaran Fisika), $3(2)$.

Eggen, P., \& Kauchak, D. (2012). Strategi dan model pembelajaran. Jakarta: Indeks.

Kang, J., \& Keinonen, T. (2017). The effect of student-centered approaches on students' interest and achievement in science: Relevant topic-based, open and guided inquiry-based, and discussion-based approaches. Research in Science Education, 1-21. https://doi.org/10.1007/s11165-016-95902

Maretasari, E., Subali, B., \& Hartono, H. (2012). Penerapan model pembelajaran inkuiri terbimbing berbasis laboratorium untuk meningkatkan hasil belajar dan sikap ilmiah siswa. Unnes Physics Education Journal, 1(2). https://doi.org/10.15294/upej.v1i2.1375

Murningsih, I. M. T., Masykuri, M., \& Mulyani,
B. (2016). Penerapan model pembelajaran inkuiri terbimbing untuk meningkatkan sikap ilmiah dan prestasi belajar kimia siswa. Jurnal Inovasi Pendidikan IPA, 2(2), 177. https://doi.org/10.21831/jipi.v2i2.11196

Ongowo, R. O., \& Indoshi, F. C. (2013). Science process skills in the Kenya certificate of secondary education biology practical examinations. Creative Education, 4(11), 713-717. https://doi.org/10.4236/ce.2013.411101

Rahmasiwi, A., Santosari, S., \& Sari, D. P. (2015). Peningkatan keterampilan proses sains siswa dalam pembelajaran biologi melalui penerapan model pembelajaran inkuiri di kelas XI MIA 9 (ICT) SMA Negeri 1 Karanganyar tahun pelajaran 2014/2015. In Seminar Nasional XII Pendidikan Biologi FKIP UNS 2015 (pp. 428-433). Surakarta: Universitas Sebelas Maret. Retrieved from https://media.neliti.com/media/publication s/174936-ID-none.pdf

Ratunguri, Y. (2016). Implementasi metode pembelajaran eksperimen untuk meningkatkan keterampilan proses sains mahasiswa PGSD. PEDAGOGIA: Jurnal Pendidikan, 5(2), 137-146. Retrieved from

http://ojs.umsida.ac.id/index.php/pedagog ia/article/view/243/pdf

Rauf, R. A. A., Rasul, M. S., Mansor, A. N., Othman, Z., \& Lyndon, N. (2013). Inculcation of science process skills in a science classroom. Asian Social Science, $9(8)$, 47. https://doi.org/10.5539/ass.v9n8p47

Saputra, A., Widoretno, S., \& Santosa, S. (2012). Increasing students science process skills and achievement through the implementation of guided inquiry learning strategy of class VIII-F SMP Negeri 5 Surakarta class year 2011/2012. Bio-Pedagogi, 1(1), 36-45. Retrieved from http://jurnal.fkip.uns.ac.id/index.php/pdg/ article/view/1120

Scott, C., Tomasek, T., \& Matthews, C. E. (2010). Thinking like a ssssscientist! Science and Children, 48(1), 38.

Subagyo, Y., Wiyanto, W., \& Marwoto, P. (2012). Pembelajaran dengan pendekatan 
keterampilan proses sains untuk meningkatkan penguasaan konsep suhu dan pemuaian. Jurnal Pendidikan Fisika Indonesia, https://doi.org/10.15294/jpfi.v5i1.999

Subekti, Y., \& Ariswan, A. (2016). Pembelajaran fisika dengan metode eksperimen untuk meningkatkan hasil belajar kognitif dan keterampilan proses sains. Jurnal Inovasi Pendidikan IPA, 2(2), 252. https://doi.org/10.21831/jipi.v2i2.6278

Sukarno, S., Permanasari, A., \& Hamidah, I. (2013). The profile of science process skill (SPS) student at secondary high school (Case study in Jambi). International Journal of Scientific Engineering and Research (IJSER) Www.ijser.in ISSN (Online, 1(1), 23473878. Retrieved from http://www.ijser.in/archives/v1i1/MDEx MzA5MTg=.pdf

Trianto, T. (2010). Model pembelajaran terpadu: Konsep, strategi, dan implementasinya dalam Kurikulum Tingkat Satuan Pendidikan (KTSP). Jakarta: Bumi Aksara. https://doi.org/2010

Udiani, N. K., Marhaeni, A. A. I. N., \& Arnyana, I. B. P. (2017). Pengaruh model pembelajaran inkuiri terbimbing terhadap hasil belajar IPA dengan mengendalikan keterampilan proses sains siswa kelas IV SD no.7 Benoa Kecamatan Kuta Selatan Kabupaten Badung. Jurnal Penelitian Pascasarjana Undiksa, 7(1). Retrieved from http://pasca.undiksha.ac.id/ejournal/index.php/jurnal_pendas/article/vi ew $/ 2242$

Ural, E. (2016). The effect of guided-inquiry laboratory experiments on science education students' chemistry laboratory attitudes, anxiety and achievement. Journal of Education and Training Studies, 4(4), 217-227. https://doi.org/10.11114/jets.v4i4.1395

Wijayanti, P. I., Mosik, M., \& Hindarto, N. (2016). Eksplorasi kesulitan belajar siswa pada pokok bahasan cahaya dan upaya peningkatan hasil belajar melalui pembelajaran inkuiri terbimbing. Jurnal Pendidikan Fisika Indonesia, 6(1). https://doi.org/10.15294/jpfi.v6i1.1093

Yuniastuti, E. (2013). Peningkatan keterampilan proses, motivasi, dan hasil belajar biologi dengan strategi pembelajaran inkuiri terbimbing pada siswa kelas VII SMP Kartika V-1 Balikpapan. EDUCATIONIST: Jurnal Kajian Filosofi, Teori, Kualitas, Dan Manajemen Pendidikan, 14(1). Retrieved from http://ejournal.upi.edu/index.php/JER/arti cle/viewFile/3509/2489 